\title{
FACTORS AFFECTING WOMEN FARMERS PARTICIPATION IN AGRICULTURAL EXTENSION ACTIVITIES IN KADUNA STATE, NIGERIA
}

\author{
Ganiyu L. ${ }^{1}$, Abdulkareem S.B. ${ }^{2}$, Anamayi R.M. ${ }^{3}$, Aasa O.S. ${ }^{2}$, Balogun 0.S. ${ }^{2}$, \\ Haruna A.Z. ${ }^{3}$, Lapkat L.G. ${ }^{4}$, Ushie F.T. ${ }^{1}$, Aaron J.A. ${ }^{1}$ \\ ${ }^{1}$ Department of Agricultural Technology, ${ }^{2}$ Department of Agricultural Extension and \\ Management, ${ }^{3}$ Department of Basic and General Studies, ${ }^{4}$ Department of Horticulture and \\ Landscape Technology, Federal College of Forestry Mechanization, Nigeria \\ ${ }^{*}$ E-mail: ganiyul457@gmail.com.
}

\begin{abstract}
The study examined the factors affecting women farmers' participation in agricultural extension activities in Kaduna State, Nigeria. Purposive sampling was used to select Lere local government area, where 5 villages were purposively selected: Saminaka, Lere, UngwaBawa, Yarkasuwa and Kayarda. Data were gathered through the administration of questionnaire to $25 \%$ randomly selected farmers from each of the 5 villages. Descriptive statistics such as frequency counts and percentage were used to describe the data while linear regression was used to examine the factors that affect participation in agricultural extension activities by women farmers. The result shows that the average age of the women is 40 years. Also, majority $(71 \%)$ of the women were married, educated $(33 \%)$, with $1-5$ household members $(67 \%)$ and most $(67 \%)$ of whom were non - members of cooperative. Furthermore, crop activities rank $1^{\text {st }}$ in the list of extension activities and most (57\%) had extension contact on quarterly basis. The level of participation showed that about half $(48 \%)$ of the women farmers highly participate in extension activities. The regression result shows that extension contact is the only significant factor that influences participation in agricultural extension activities in the study area. The involvement of women farmers in cooperative societies and regularity of extension visit was recommended.
\end{abstract}

\section{KEY WORDS}

Farmers, women, Nigeria, public service, agriculture.

The role of women in agricultural development has been very well recognized in the last couple of decades by international development agencies, national governments and researchers (FAO, 2010). Rural woman in Nigeria plays an essential role in the four pillars related to food security: availability, accessibility, stability and utilization. However, based on gender issue these women in rural areas are at a disadvantage due to the fact that they do not have access to the same opportunities or resources as men (Babasanya et al., 2021). There is a wide gender gap as regards access to certain resources such as: land, energy, technology, loans, pesticides and fertilizers. Furthermore, women have more limited access to training, information, public services, social protection and markets (FAO, 2013).It was further indicated that while the contributions of both female and male farmers were substantial and essential to agricultural extension, the gender division of agricultural activities has constrained women's access to extension services because agricultural extension services in developing countries is predominantly focusing male farmers only.

Franklin (2011) asserted that women's low participation in national and regional policymaking, their invisibility in national statistics and their low participation in extension services suggested that these issues of most concern to women have been neglected in the design and implementation of development policies and programs. In countries such as Nigeria, the programs developed were far from addressing the main concerns of women as they were neither involved in policy making decisions nor were they directly consulted to articulate their needs. According to Ugboh (2014), agricultural improvement initiative which ignores the impact of women's participation in agricultural development can at best achieve 'false 
growth'. It is therefore necessary that to be effective, the policies, programs, projects and target should address women's specific issues.

Consequently, development, food security and poverty alleviation will not be truly achieved without rapid agricultural growth which will directly or indirectly touch rural women. Assisting the rural poor to achieve their livelihoods and food security in a sustainable manner is therefore, a great challenge. Broadly, increase in agricultural productivity is central to growth, income distribution, improved food security and alleviation of poverty in rural Africa (FAO, 2012). In all these, the rural women plays pivotal roles to the overall success of efforts directed at agricultural development in rural areas.

A good number of studies have revealed that; three out of four poor people in the developing world live in rural areas, and most of these people depend directly or indirectly on agriculture as their main source of livelihoods (Adekanye, Ogunjimi, and Ajala, 2013). Many agricultural development activities are on ground with the aim of increasing food production and improving the standards of living in Nigeria. Although women farmers are actively involved in the process of food production, processing and marketing, social and economic constraints have placed barriers around their access to scientific and technological information (Daman, 2017).

Women participation in agricultural extension and agricultural development has been neglected and faced with serious challenges. Women policy in agriculture has been left without giving proper attention and through investigation, their level of participation has been minimal compare to men. Thus, Women tend to have less contact with extension services than men and generally use lower levels of technology because of problems of access, cultural restrictions on use or lesser interest in doing research on women's crops and livestock (World Bank, 2013).

The potential for effective contribution by women to the process of agricultural and rural development had been globally reduced by the adoption of socio-economic policies and programs that tend to be less responsive to the development needs of rural women (Babasanya et al., 2021).

Effective agricultural extension services appear important issue in Nigeria, where agriculture supports $85 \%$ of employment, $50 \%$ of exports, and $50 \%$ of gross domestic product (NBS, 2010). This is because agricultural extension services were proved to be one of the most important effective means to reach farming households in the rural areas (Adekunle, 2013). Agricultural extension services should be competitive and complementary to rural women. However, in Nigeria there is a wide gender gap in terms of access to assets (i.e. land, livestock, credit, and inputs) (World Bank, 2008). Furthermore, programs and projects that do not pay due attention to women in their activities, often widens existing inequalities between men and women, particularly in Igabi, Kaduna State, where women in most parts of the rural area are involved in most aspects of agricultural production and household nutrition, leaving farming to men.

With regard to the aforementioned problems, this study investigated the factors affecting women farmers' participation in Agricultural Extension Activities in Kaduna State.

The specific objectives are to: describe the socio-economic characteristics of the respondents in the study area; identify various agricultural extension activities in the study area; determine the level of participation of women farmers in agricultural extension service in the study area; identify the factors influencing women farmers' participation in agricultural extension service in the study area.

Research Hypothesis:

- $\mathrm{H}_{0 \text { : }}$ There is no significant relationship between the socio-economic factors and the participation of women farmers in agricultural extension activities in the study area.

\section{METHODS OF RESEARCH}

The study was conducted in Lere local government area of Kaduna state. Headquarter of the local government area is located in Saminaka. The local government area was created in the year 1991 out of the former Saminaka local government area created in1976. The local 
government is located between latitude $9^{\circ} \mathrm{N}$ and $12^{\circ} \mathrm{N}$ and longitude $6^{\circ} \mathrm{E}$ and $9^{\circ}$ Eof prime meridian. The total land area is about $21,158 \mathrm{~km}^{2}$ and a population of 331,161 (NPC,2006). It shares boundary with Kanostate in the northern part, while in the area towards eastern part it is bounded by Bauchi and Plateau states. In addition to the abovementioned, other important area around Lere local government include the ancient city of Zariato the north. It is bordered by the commercial town of Kafanchan down south. The study area has many villages among which are Lere, Saminaka, Kayarda, Ungwan-Bawa, Yarkasuwa,Garu, Gure, Dokandanbala and Lazuru among many others. The climate in Lere local government can be divided into three seasons, this start with the hot and sunny season which begins from February to early May, followed by the raining season from March to October. Crops commonly grow in the area include, yam, millet, beans, soya beans, tomatoes, onion, sugar cane, rice, ground nut, cucumber, cabbage and potatoes.

Primary data was used for this study. The primary data was sourced through administering of a well-structured questionnaire and oral interview to the women farmers. The questionnaire that contained both open-ended and multiple choice questions relating to women farmers socio-economic characteristics, types of extension activities and the women participation in the activities were administered to the farmers by the researchers through physical contact.

Multi-stage, purposive and random sampling techniques were adopted to select the respondents for the study. In the first stage, Lere local government area was selected from the state purposively due to high concentration of extension activities in the area. In the second stage, five (5) villages were also purposively selected (as a result of concentration of women farmers) which includes; Saminaka, Lere, Ungwa-Bawa, Yarkasuwa and Kayarda. Based on the population and concentration of the women farmers in these areas, 19 respondents each were selected from Saminaka and Lere while 20respondents each were selected from Kayarda and Ungwa-Bawa and 12 respondents from Yarkasuwa. This gave a total of ninety (90) respondents that were used for the study.

Primary data, descriptive and inferential statistics was used for the study. Descriptive statistics such as simple percentage was used to achieve objective (i), (ii), (iii) and (v).

The regression analysis was used to examine the factors that influence women farmers participation in agricultural extension activities in the study area (iv).

The linear model specification in its implicit form is given by:

$$
Q=f\left(X_{1}, X_{2}, X_{3}, X_{4}, X_{5}, X_{6}, X_{7}, X_{8}, X_{9}, X_{10}, \mu\right)
$$

The model is explicitly specified in the form below:

$$
Q=a+b_{1} X_{1}+b_{2} X_{2}+b_{3} X_{3}+b_{4} X_{4}+b_{5} X_{5}+b_{6} X_{6}+b_{7} X_{7}+b_{8} X_{8}+b_{9} X_{9}+b_{10} X_{10}+e
$$

Where: $Q=$ Participation ( $1=y e s ; 0=n o) ; X_{1}=$ Age (years); $X_{2}=$ Education $(0=$ no; 1 = primary; 2 = secondary; 3 = tertiary; $4=$ quranic $) ; X_{3}=$ Marital status $(1=$ single; 2 = married; 3 = divorced; 4 = widow); $X_{4}=$ Household size (number of persons); $X_{5}=$ Farming experience (years); $X_{6}=$ Membership of cooperative $(0=$ no; $1=y e s) ; X_{7}=$ Extension contact ( $1=$ quarterly; $2=$ monthly; $3=$ fortnightly; $4=$ weekly); $X_{8}=$ Access to credit $(0=$ no; $1=y e s) ; X_{9}=$ Income (naira); $\mathrm{X}_{10}=$ Puddah $(0=$ no; $1=y e s) ; b_{1}-b_{9}=$ Regression coefficients; $a=$ constant; $e=$ error term.

\section{RESULTS AND DISCUSSION}

Results showed that $44.4 \%$ of the women farmers were between the age range of 31 and 40 years. This is followed by $38.9 \%$ who were 30 years and below while only $16.7 \%$ were in the age range of 41 and 50 years. This implied that young women participate more in extension activities in the study area. This is in line with the submission of Adeleke et al. (2016) that the rural women involving in economic empowerment program of Ogun State Agricultural Development Program are between $41-50$ years. Also, Olagunju et al. (2021) opined that most of the rural women participating in fish farming were youth; $33 \%$ of the 
women farmers participating in agricultural extension activities had tertiary education. This means that the participants will be able to read and write, thereby exploring the opportunities of agricultural value chains provided through extension information in leaflets and bulletins. Furthermore, majority $(71 \%)$ of the women farmers were married, implying that family labour will be readily available for use in participation in agricultural extension activities in the area. However, majority (67\%) of those with small family size participate more in extension activities that those with large family size.

The monthly income of women farmers shows that $35.56 \%$ of them realized above $\$ 50,000$ in a month. This is followed by $25.56 \%, 18.89 \%$, and $12.22 \%$ of the women population that realized $\$ 31,000-40,000, \$ 21,000-30,000$ and $\$ 11,000-20,000$ respectively. Only $4.44 \%$ and $3.33 \%$ realized $\$ 41,000-50,000$ and $\geq \$ 10,000$ in the study area. This means that the women farmers are subsistence farmers who engage in crop activities to support the family. This agrees with the study by Olagunju et al. (2020) that assessed participation level of rural women in fish farming in Kaduna State and found out that $38.3 \%$ of them realized above $\$ 50,000$ per month.

However, majority (67\%) of the women farmers were non-members of association and thus do not have access to credit facilities (72\%).

Most $(66.7 \%)$ of the women farmers do not belong to cooperative societies and as such do not have access to credit $(72.2 \%)$. Extension visits is mostly $(57 \%)$ on quarterly basis with majority $(86 \%)$ of women farmers participating in agricultural extension activities in the study area.

The women farmers involvement in extension activities in the study area shows that $18.22 \%$ of the women engaged in crop activities, and was ranked 1 st. This is closely followed by those who engaged in processing activities (17.34\%) and marketing (14.22\%) which ranked $2^{\text {nd }}$ and $3^{\text {rd }}$ respectively. Other extension activities in the study area include: farmers group formation $\left(4^{\text {th }}\right)$; radio broadcast $\left(5^{\text {th }}\right)$; farmers education meeting $\left(6^{\text {th }}\right)$; house visit $\left(7^{\text {th }}\right)$; TV advertisement $\left(8^{\text {th }}\right)$; extension dissemination plot $\left(9^{\text {th }}\right)$; and reading leaflets $\left(9^{\text {th }}\right)$. This implies that crop related extension activities are mostly carried out by the women farmers in the study area.

Table 1 - Distribution of respondents by the types of extension activities carried out

\begin{tabular}{|l|l|l|l|}
\hline Activities & Frequency & Percentage \\
\hline Radio broadcast & 23 & 10.22 & Rank \\
\hline House visit & 21 & 9.33 & 5 th \\
\hline Crop activities & 41 & 18.22 & 7 th \\
\hline Farmers education meeting & 22 & 9.78 & $1 \mathrm{st}$ \\
\hline Extension dissemination plot & 5 & 2.22 & 6 th \\
\hline Farmers group formation & 24 & 10.67 & 9 th \\
\hline Tv advertisement & 13 & 5.78 & \\
\hline Processing activities & 39 & 17.34 & \\
\hline Marketing & 32 & 14.22 & 2 th \\
\hline Reading leaflets & 5 & 2.22 \\
\hline Total & 225 & 100 \\
\hline
\end{tabular}

*Multiple responses.

Majority (86\%) of women farmers in the study area participate in agricultural extension activities. Only $14.4 \%$ of them do not participate in extension activities implying that women farmers in the area generally take part in extension activities in the study area.

The level of women participation in extension activities shows that $47.8 \%$ of the women farmers highly participate in extension activities while $37.8 \%$ and $14.4 \%$ were moderately and lowly involved in extension activities. This implies that the women farmers are highly involved in extension activities. This is in tandem with the findings by Ojo et al. (2016) where it was opined that farmers highly (55.8\%) participate in adopted villages' activities of Federal agricultural colleges in Oyo State.

The results depicted that among the factors considered; extension contact and puddah are the only significant factors that influence participation in agricultural extension activities in the study area. While extension contact coefficient (0.337) is positive and significantly related 
to participation at $1 \%$ level of significance, puddah positively $(0.053)$ and significantly influenced participation in extension activities at $10 \%$. This implies that the more the extension contact, the more the participation of women in extension activities in the study area. Also, the more the women practice puddah, the more their participation in extension activities. This is similar to the findings by Ganiyu et al. (2016), where it was observed that extension contact influenced farmers' adoption of social forestry practices. The study however negates the apriori expectation for puddah.

Table 2 - Distribution of respondents by level of participation in extension activities

\begin{tabular}{|l|l|l|}
\hline Participation level & Frequency & Percentage \\
\hline High & 43 & 47.8 \\
\hline Moderate & 34 & 37.8 \\
\hline Low & 13 & 14.4 \\
\hline Total & 90 & 100 \\
\hline
\end{tabular}

The adjusted $R^{2}$ value of 0.270 implies that the specified independent variables in the model collectively explain $27 \%$ of the variation in the participation (dependent variable) of agricultural extension activities in the study area. The remaining $73 \%$ was due to other factors that were not included in the model.

Based on the findings of the study, the hypothesis that socioeconomic factors have no significant effect on the participation of women farmers in agricultural extension activities in the study area was accepted because socioeconomic factors do not influence participation.

Table 3 - Linear Regression result of factors influencing participation in agricultural extension activities

\begin{tabular}{|c|c|c|c|c|}
\hline Variables & Coefficient & Standard error & T - Values & Sig \\
\hline Constant & & 0.104 & 5.019 & 0.000 \\
\hline Age & -0.227 & 0.136 & -1.684 & 0.096 \\
\hline Education & 0.120 & 0.137 & 0.883 & 0.380 \\
\hline Marital status & -0.298 & 0.149 & -2.005 & 0.048 \\
\hline Household size & -0.164 & 0.141 & -1.178 & 0.242 \\
\hline Farming experience & -0.044 & 0.123 & -0.361 & 0.719 \\
\hline Membership of cooperative & 0.151 & 0.145 & 1.389 & 0.169 \\
\hline Extension contact & 0.337 & 0.126 & 3.562 & $0.001^{* * *}$ \\
\hline Access to credit & 0.083 & 0.119 & 0.743 & 0.460 \\
\hline Income & 0.210 & 0.109 & 0.502 & 0.617 \\
\hline Puddah & 0.053 & 0.129 & 1.726 & $0.088^{*}$ \\
\hline
\end{tabular}

${ }^{* * *}=1 \% ;{ }^{*}=10 \%$ adjusted $R^{2}=0.270$.

The challenges of women farmers' participation in agricultural activities reveal that inadequate capital ranked $1^{\text {st }}$ in the list of challenges. This is closely followed by land tenure problem, distance, lack of understanding and quarrel among members, thus, ranking $2^{\text {nd }}, 3^{\text {rd }}$, $4^{\text {th }}$ and $5^{\text {th }}$ respectively. Other challenges faced by the women farmers include: lack of incentives $\left(6^{\text {th }}\right)$, illiteracy $\left(7^{\text {th }}\right)$, bad leader $\left(8^{\text {th }}\right)$, electricity $\left(8^{\text {th }}\right)$, government policy $\left(10^{\text {th }}\right)$, poor information dissemination $\left(10^{\text {th }}\right)$, and lastly, wrong timing $\left(12^{\text {th }}\right)$. The implication of this is that availability of capital is an important motivational factor for participation in agricultural extension activities in the study area. This is in line with the submission by Akinola et al., (2007) that availability of capital influenced rural women involvement in agro-processing in Kaduna State.

\section{CONCLUSION AND RECOMMENDATIONS}

The findings of the study showed that crop activities top the list of extension activities participation by the women farmers. Furthermore, the level of participation of women in agricultural extension activities is high (47.8\%) while extension contact significantly affects women farmers' participation in agricultural extension activities in the study area.

Since the study revealed that the women farmers were chiefly $(66.7 \%)$ non-members of cooperative societies, effort should be made by the extension service providers to encourage 
the women to join cooperative societies so that they can access fund from financial institutions.

Similarly, extension contact positively affects participation in agricultural extension activities. Therefore, the frequency of visit of extension workers should be more regular as against the quarterly visit (56.7\%) observed by this study.

Finally, adequate capital should be provided for women farmers by the government to stimulate their interest in participation in agricultural extension activities in the study area, since inadequate capital top the list of the challenges in participation.

\section{REFERENCES}

1. Adeleke, A.I., Adeoye, A.S., and Odedeji, A.D. (2016). Challenges to rural women economic empowerment program in Agricultural Development Program in Ogun State. Proceedings of the $21^{\text {st }}$ Annual Conference of the Agricultural Extension Society of Nigeria (AESON), University oflbadan, Nigeria. $17^{\text {th }}-20^{\text {th }}$ April, 2016, Pp $160-169$.

2. Adekanye, T.A., Ogunjimi, S.I and Ajala, A.O (2013). An assessment of cassava processing plants in Irepodum Local Government Area of Kwara State, Nigeria. World Journal of Agricultural Research 1 (1): 14-17.

3. Akinola, M.O; Iyela, U.B.M. and Ogunbameru, B.O. (2007). Socio-economic Analysis of Rural Women's Involvement in Agro-Processing in Sabon-gari LGA, Kaduna State. In: Olufajo, O.O.; Omokore, D.F.; Akpa, G.N. and Sanni, S.A. (eds). Proceedings of the $41^{\text {st }}$ Annual Conference of the Agricultural Society of Nigeria (ASN), Ahmadu Bello University, Zaria, 22 - 26 October, 2007. Pp $616-617$.

4. Asawalam, D.O. and Chukwu, G.O. (2011). Land capability evaluation of Ikwuano Local Government Area of Abia State for agricultural development. Proceedings of $25^{\text {th }}$ Annual Conference of Soil Science Society of Nigeria, Benin City, Edo State, 21st -29th November, 2011.Pp 39-44.

5. Babasanya, B., Abdulkareem, S.B., Ganiyu, L., Balla Uzza, Adetunji, Adeniyi J., Ademola, T. Oluwole, Omodona, S., Olafemi, S.O. and Usman, M.B. (2021). Role of Women in Food Security in Nigeria. European Modern Studies Journal, 5 (3) 511 - 516.

6. Daman, P. (2017). Cooperation and poverty reduction enhancing social and economic imperatives. ICA Road, New Delhi: PS.

7. FAO (2012). Report to "The new partnership for Africa's development" Land and water resources issues and agricultural development. $22^{\text {nd }}$ regional conference for Africa, Cairo, 4- $8^{\text {th }}$ February.

8. FAO (Food and Agricultural Organization) (2010). Training of man power for agricultural and rural development in Africa. ARC/84/3; Rome, Italy.

9. FAO. (2013). Training Guide: Gender and climate change research in agriculture and food security. Retrieved April 10, 2020, from: http://www.fao.org/

10. Franklin, T. (2011). Gender inequality in Nigeria. Taking IT Global online Publications, $31^{\text {st }}$ May, Pp 1-19.

11. Ganiyu, L., Abdulkareem, S.B., Babasanya, B., Oladele, G.O. and Olumuyiwa, S. (2016). Socio- Economic Factors Influencing the Adoption of Social Forestry Practices by Farmers in BirninGwari Local Government Area of Kaduna State. Proceedings of the $21^{\text {st }}$ Annual Conference of the Agricultural Extension Society of Nigeria (AESON), University of Ibadan, Nigeria. $17^{\text {th }}-20^{\text {th }}$ April, 2016, Pp $193-200$.

12. National Population Commission (NPC). (2006). National Population Commission, 2006 Population Census Figure.

13. Ojo, A.O., Olujide, M.G., Adelakun, O.E., Omisope, E.T. (2016). Participation of farmers in adopted villages' scheme activities of Federal Agricultural Colleges in Oyo Stata. Proceedings of the $21^{\text {st }}$ Annual Conference of the Agricultural Extension Society of Nigeria (AESON), University oflbadan, Nigeria. $17^{\text {th }}-20^{\text {th }}$ April, 2016, Pp $108-116$.

14. Olagunju, O.E., Ariyo, O.C., Olagunju, O.S., Fadele, O.K., Alabi, O.F., Ganiyu, L., and Ademuwagun, A.A. (2021). Assessment of participation level of rural women in fish 
farming in Kaduna State, Nigeria. Russian Journal of Agriculture and Social Sciences, 3 (111) $141-149$.

15. Olagunju, O.E., Oluyaire ,B.,Ganiyu, L., Olagunju, O.S., Olorukooba, M.M., Olafemi, S.O. and Tor, L. G. (2020). Knowledge and Attitude of Rural Women towards Agroforestry Practices in Kaduna State. Asian Journal of Agricultural Extension, Economics and Sociology. 38 (12) $11-21$.

16. Ugboh, A. (2014): Women role in agricultural production. A paper presented in a seminar on women-employment at Abuja in (August 11th).

17. World Bank (2013).Nigeria: Women in Agriculture. In Sharing Experiences-Examples of Participating Approach. The World Bank Group, The World Bank Participating sourcebook, Washington D.C. Retrieved July 13, 2010 from www.worldbank.org.

18. World Bank (2008): Annual report. The world women Trends and statistics 1970-1990 New York. 